\title{
レーダ雨量情報を用いて洪水調節を確率的に行うための 基礎的検討
}

\author{
A STUDY ON PROBABILITY RUN-OFF FORECASTING METHOD \\ FOR FLOOD CONTROL USING RADAR RAIN GAUGE
}

上林好之*

By Yoshiyuki KANBAYASHI

\begin{abstract}
Only the average precipitation in a few hours preceding to the forecast usually has been used as input data for flood forecasting models. However, this method does not correctly evaluate the difference between expected value and actual observed value of discharge.

This paper proposes a method which evaluates the discharge and the water level in probability, by studying the forecast rainfalls probability distribution by means of Radar Rain Gauge (including Digitized Weather Radar) precipitation forecast methods, and by inputting the result into the run-off models as a group of forecast rainfalls.

The examination on the application led to the conviction that this new method can bring about practical and useful information.

Keywords : short-term rainfall forecasting, precipitation forecast probability distribution, probability run-off forecasting method, use of probability runoff forecast, Radar Rain Gauge
\end{abstract}

\section{1. まえがき}

レーダ雨量計はデジタル化された気象レーダを含める 亡全国で約 30 基が運用されている.わが国における河 川は一般的に洪水の到達時間が短いことから，ダム貯水 池による効率的な洪水調節や河川構造物のゲート操作に 降雨予測に基づく洪水流出予測の重要性が認められ，著 者ら ${ }^{1)}$ はレーダ雨量計による雨量情報が地上の雨量計に よる雨量に近い定量值として得られるようレーダ定数

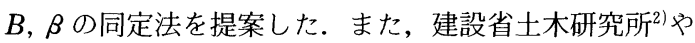

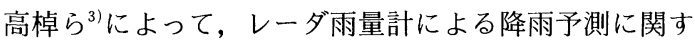
る研究がなされているが，予測時間が長くなるにつれて 予測精度が低下すること, あるいは, 予測降雨の期待値 を入力した場合, 降雨の予測方法によっては洪水流出量 が大きく変動する4)ことから, 洪水流出モデルの入力情 報として利用されるまでには至っていない.

本文は高棹ら ${ }^{5)}$ が地上雨量計のデータから降雨予測值 の分散が予測時間と雨量強度の二乗に比例するという仮 定のもとに洪水流出の確率予測の研究を行っていること に着目して，レーダ雨量計による降雨予測結果をもとに この仮定を検討し，その妥当性を検証した．そこで，ダ

* 正会員（財）河川情報センター理事

（１02 千代田区数町 1-3）
ム貯水池による洪水調節に，レーダ雨量計による予測降 雨に誤差確率の考えをとり入れた洪水流出予測結果を利 用する検討を行ったところ，実用的に有用な情報となり 得ると考えられることから，検討成果を報告することと した。

2. レーダ雨量計による短時間降雨予測手法と 精度

レーダ雨量計を用いた降雨予測手法は，すでに(1)高層 風による手法 ${ }^{6)}$, (2)相互相関関数法 ${ }^{7), 8)}$, (3)関連係数法 ${ }^{2), 9)}$, (4)合成予測法 ${ }^{10)}$, (5)ベクトル内挿法 ${ }^{11)}$, (6)変形テンソル

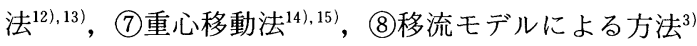
等が提案されている.これらの予測精度を判断する共通 の指標として相関係数についてまとめたものが表一1で ある.それぞれ対象降雨および評価単位面積が異なるの で，この表から予測手法の優劣はつけられないが，いず れの手法においても予測時間が 2 時間先， 3 時間先と長 くなるにつれて一般的に精度が低下していることが理解 される.

\section{3.レーダ雨量計による短時間降雨予測確率分 布の検討}

吉野ら ${ }^{16)}$ は，多くの予測結果を処理して予測値の信頼 
表-1 降雨予測方法の比較

\begin{tabular}{|c|c|c|c|c|c|c|c|c|}
\hline 手 & & 関 & 連 & 係 & \multicolumn{2}{|l|}{ 法 } & 合成予測法 & 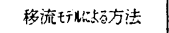 \\
\hline \multicolumn{2}{|c|}{ 奏施涉閏（年度) } & 土木研究所（62） & \multicolumn{2}{|c|}{ 筑俊川就管 $(60)$} & \multicolumn{2}{|c|}{ 筑谖川殁統管 (61) } & 淀川ダ二䊺管 $(60)$ & 京大工学部 (59) \\
\hline \multicolumn{2}{|l|}{$\begin{array}{l}\text { 対象降雨数 } \\
\text { (I.. F. FY. TH) }\end{array}$} & (1. 3.4 . 0 & \multicolumn{2}{|c|}{ 1. $\left.{ }^{8} .2 .0\right)$} & \multicolumn{2}{|c|}{$(1.5,0.0)$} & (2. $5,6,7)$ & (雷 ${ }^{1}$ 雨) \\
\hline \multicolumn{2}{|c|}{ 移動バクトル算出時間 } & 15 分 & \multicolumn{2}{|r|}{15 分 } & \multicolumn{2}{|c|}{15 分 } & 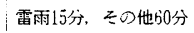 & 過去万分 \\
\hline \multicolumn{2}{|l|}{ 地形性勃果 } & 無 & \multicolumn{2}{|r|}{ 立平モデル } & \multicolumn{2}{|c|}{ 立平モデル } & 地形によって異ふる & 無 \\
\hline \multicolumn{2}{|l|}{ 発迋减要項 } & 無 & \multicolumn{2}{|c|}{ 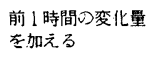 } & \multicolumn{2}{|c|}{$\begin{array}{l}\text { 前 } 1 \text { 時間贾化墨を5分 } \\
\text { の1 加える }\end{array}$} & 回帰式て推定 & $x, y$ 座摽の一次式 \\
\hline \multicolumn{2}{|c|}{ キーリブレーンョン } & 無 & \multicolumn{2}{|r|}{ 無·有 } & \multicolumn{2}{|c|}{ 無 } & 無 & - \\
\hline \multicolumn{2}{|c|}{$\begin{array}{l}\text { 情度評価対象領域 } \\
\text { (面)櫝) }\end{array}$} & $\begin{array}{c}15 \times 15 \mathrm{~km} \times \\
225 \mathrm{kmi}\end{array}$ & \multicolumn{2}{|c|}{$\begin{array}{l}1 \text { 流域 } \\
\text { 約 } 8010 \mathrm{kmi}\end{array}$} & \multicolumn{2}{|c|}{$\begin{array}{c}5 \text { 流域及ご各代表地点 } \\
40 \sim 800 \mathrm{~km} .9 \mathrm{kmi}\end{array}$} & $\begin{array}{c}\text { 近㖪地建管内各流域 } \\
80 \sim 3850 \mathrm{~km}\end{array}$ & $\begin{array}{c}\text { 木津川流域 } \\
1600 \mathrm{kmi}\end{array}$ \\
\hline \multirow{3}{*}{$\begin{array}{l}\text { 相関䛿数 } \\
\text { (平均的坛) }\end{array}$} & 1 時間 & 0.76 & & 0.91 & 0.88 & 0.81 & 0.75 & $0.9 \hat{b}$ \\
\hline & 2 時問 & 0.43 & & 0.48 & 0.58 & $0.4 i$ & 0.48 & 0.32 \\
\hline & 3 時間 & $0.3 i$ & & 0.37 & 0.33 & 0.26 & 0.30 & 0.75 \\
\hline \multicolumn{2}{|c|}{ 去つ他の誤差指漂 } & 適中率, C. S. I etc & 平 & 均㑟差 & 平均 & 說差 & 変動 係数 & $\therefore$ \\
\hline
\end{tabular}

注 $\mathrm{L}$ ， L : 低気圧, $F$ : 前楾, TY : 台風, TH : 雷雨

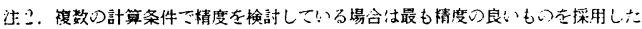

限界を明らかにしている。一方，高棹ら ${ }^{5)}$ は，地上雨量 計のデータから，予測值の分散が予測時間 $l$ と実測値の 二乗に比例するとし, 分散と予測時間, 雨量強度の関係 を次のように提案している.

$$
\begin{aligned}
& E\left[\hat{R}_{k+l}\right]=R_{k+l} \cdots \ldots \ldots \ldots \ldots \ldots \\
& V\left[\hat{R}_{k+l}\right]=S_{k+l}^{2}=a_{p}^{2} \cdot l \cdot R_{k+l}^{2}
\end{aligned}
$$

ここに, $E\left[\hat{R}_{k+l}\right]: \hat{R}_{k+l}$ の期待値

$$
V\left[\hat{R}_{k+l}\right]: \hat{R}_{k+l} \text { の分散 }
$$

$R_{k+l}:$ 時刻 $k$ から $l$ 時間先の降雨の実測 值

$\hat{R}_{k+l}: k+l=1,2, \cdots$ シミュレートされる 降雨の予測值

$S_{k+l}$ : 時刻 $k+l$ における降雨の予測值の 標準偏差

$a_{\rho}(\geqq 0)$ : シミュレートされた降雨の予測值の 予測精度を制御するパラメーター

上式の概念を図で示したものが，図一1である。これは 予測時間が長くなるほぼ，また降雨強度が大きくなるほ ぞ精度が悪くなるという仮定に基づいている。

そこで，八重岳レーダ雨量計を用いて，昭和 60 年か ら 62 年の 3 か年の主要 12 降雨を対象に, 移流モデルに よる方法および関連係数法の 2 手法を用いた降雨予測結 果とレーダ雨量計で観測した降雨の実測値を $9 \mathrm{~km} \times 9$ $\mathrm{km}$ の方形領域に整理し，予測值の階級別に統計処理し たところ表一2に示す結果が得られた。

表一2では，予測值の階級別の実測值の平均值 $\bar{R}_{k+i}$ と $\bar{R}_{k+l}$ に対する予測值の分散 $V\left[\hat{R}_{k+l}-\bar{R}_{k+l}\right]$ および予 測時間 $l$. と分散 $V$ の関係 $\sqrt{V / l}$ を整理している.

表一2によると予測值の期待値と実測值は必ずしも一

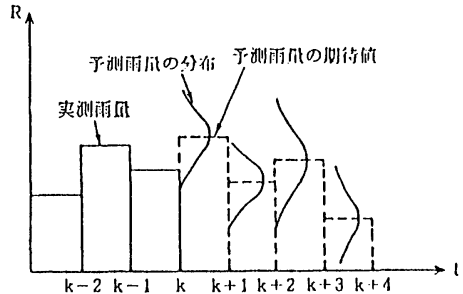

図一-1予測雨量の期待值と分散 ${ }^{3)}$

致せず，予測值に比べ実測値の方が小さくなる傾向を示 し，厳密には式（1）が成立していない。しかし，今回 のサンプルは，地域および降雨成因が限定されたもので あり，今後，広範な地域で同様な検討を行う必要のある ことが課題として残されていることから，ここでは，式 （1）が成立するものとして以下検討を進めていく.

図一2 は表一2に示した $\bar{R}_{k+l}$ 之 $\sqrt{V / l}$ の関係を図示 したものであり，デー夕数の少ない強降雨強度域を除く 之 $\bar{R}_{k+l}$ 之 $\sqrt{V / l}$ の関係は一次式で近似されることを示 している．すなわち，式（1）が成立するとの前提にた てば，式（2）の仮定はほぼ成立するものと考えられ， 図一2 の回帰直線の傾きは式 $(2)$ に示す $a_{p}$ を与える ことになり，移流モデルによる方法，関連係数法の $a_{p}$ はおのおの $0465 ， 0.480$ と同定される.

したがって，予測降雨として，式（1)，式（2）を 満足する正規分布に従う予測降雨（降雨予測の結果得ら れた降雨の予測値）群を発生させ，これを洪水流出モデ ルに入力することで, 流量・水位を確率的に把握するこ とが可能になる，ただし，実際に降雨予測を行う場合に は，将来の降雨の真值が不明であることから，ここでは 
表一2 八重岳レーダによる降雨予測結果

\begin{tabular}{|c|c|c|c|c|c|}
\hline $\begin{array}{c}\text { 予利 } \\
\text { 時問 } \\
\ell\end{array}$ & $\begin{array}{c}\text { 予测值 } \\
\text { の階級 } \\
\hat{\mathrm{R}}_{k+2}\end{array}$ & $\begin{array}{l}\text { サンプル } \\
\text { 数 }\end{array}$ & $\begin{array}{l}\text { 実 㣜 值 } \\
\text { の 平均 } \\
\bar{R}_{k+\ell}\end{array}$ & $\sqrt{V\left[\hat{R}_{k+l}-\bar{R}_{k+l}\right]}$ & $\sqrt{\mathrm{V} / \ell}$ \\
\hline 先 & $\begin{array}{l}4 \sim 6 \mathrm{~mm} \\
6 \sim 10 \\
10 \sim 15 \\
15 \sim 20 \\
20 \sim 30 \\
30 \sim\end{array}$ & $\begin{array}{r}7.136 \\
6.747 \\
2.408 \\
596 \\
261 \\
41\end{array}$ & $\begin{array}{l}5.0 \mathrm{~mm} \\
7.1 \\
10.4 \\
14.1 \\
19.9 \\
29.2\end{array}$ & $\begin{array}{l}2.11 \mathrm{~mm} \\
2.73 \\
3.74 \\
4.92 \\
5.98 \\
9.53\end{array}$ & $\begin{array}{r}2.98 \\
3.86 \\
5.29 \\
6.96 \\
8.46 \\
13.48\end{array}$ \\
\hline $\begin{array}{l}1 \\
\text { 時 } \\
\text { 間 } \\
\text { 先 }\end{array}$ & $\begin{array}{l}6 \sim 8 \mathrm{~nm} \\
8 \sim 10 \\
10 \sim 15 \\
15 \sim 20 \\
20 \sim 30 \\
30 \sim 50 \\
50 \sim\end{array}$ & $\begin{array}{r}5,089 \\
4,071 \\
6,833 \\
3.228 \\
2.086 \\
586 \\
46\end{array}$ & $\begin{array}{r}7.4 \\
9.1 \\
11.4 \\
14.9 \\
19.2 \\
26.5 \\
39.0\end{array}$ & $\begin{array}{r}4.25 \\
4.74 \\
5.38 \\
6.17 \\
8.17 \\
10.52 \\
14.68\end{array}$ & $\begin{array}{r}4.25 \\
4.74 \\
5.38 \\
6.17 \\
8.17 \\
10.52 \\
14.68\end{array}$ \\
\hline $\begin{array}{l}2 \\
\text { 時 } \\
\text { 間 } \\
\text { 先 }\end{array}$ & $\begin{array}{l}6 \sim 8 \mathrm{~mm} \\
3 \sim 10 \\
10 \sim 15 \\
15 \sim 20 \\
20 \sim 30 \\
30 \sim 50 \\
50 \sim\end{array}$ & $\begin{array}{r}4,123 \\
3,302 \\
5.580 \\
2.722 \\
1.899 \\
512 \\
45\end{array}$ & $\begin{array}{r}7.3 \\
7.9 \\
9.1 \\
10.6 \\
11.6 \\
13.0 \\
13.7\end{array}$ & $\begin{array}{r}6.54 \\
6.66 \\
6.83 \\
7.78 \\
8.01 \\
10.02 \\
10.01\end{array}$ & $\begin{array}{l}4.62 \\
4.71 \\
4.83 \\
5.50 \\
5.66 \\
7.09 \\
7.08\end{array}$ \\
\hline $\begin{array}{l}3 \\
\text { 時 } \\
\text { 間 } \\
\text { 先 }\end{array}$ & $\begin{array}{l}6 \sim 8 \mathrm{~mm} \\
8 \sim 10 \\
10 \sim 15 \\
15 \sim 20 \\
20 \sim 30 \\
30 \sim 50 \\
50 \sim\end{array}$ & $\begin{array}{r}3.343 \\
2.711 \\
4.434 \\
2.295 \\
1.641 \\
433 \\
57\end{array}$ & $\begin{array}{l}6.1 \\
6.7 \\
7.1 \\
7.5 \\
8.0 \\
8.2 \\
6.4\end{array}$ & $\begin{array}{l}6.64 \\
6.81 \\
6.64 \\
6.69 \\
6.73 \\
7.39 \\
7.42\end{array}$ & $\begin{array}{l}3.83 \\
3.93 \\
3.83 \\
3.86 \\
3.89 \\
4.27 \\
4.28\end{array}$ \\
\hline
\end{tabular}

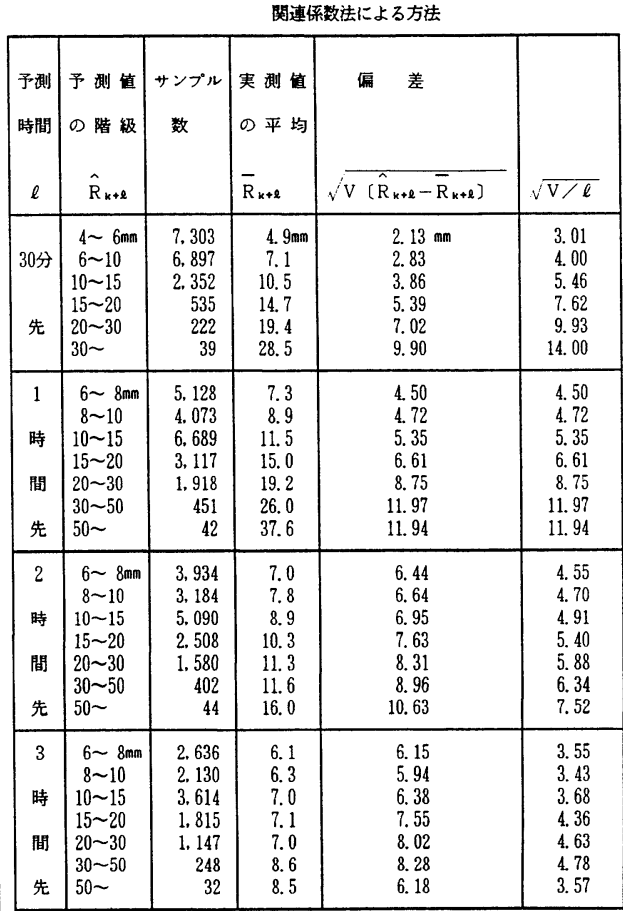

注）降雨予測手法によりサンプル数および実測值の平均が異なるのは予測手法により予測可能領域が異なるためである.
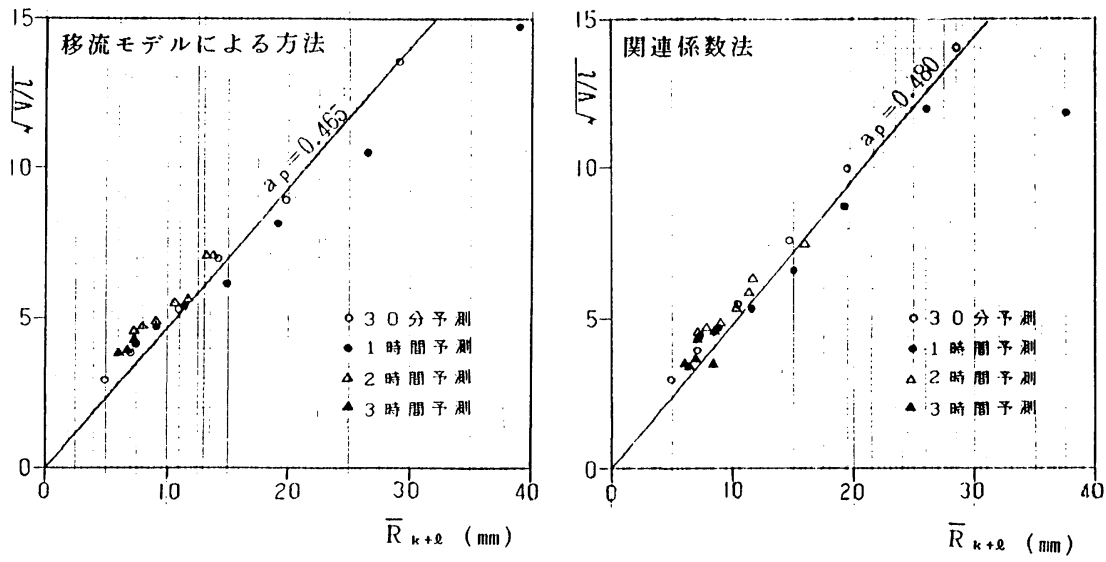

図-2 $\overline{\boldsymbol{R}}_{k+l}$ と $\sqrt{V / l}$ の関係

移流モデルによる方法もしくは関連係数法により算出さ れた予測降雨 $\hat{R}_{k+l}$ が $E\left[\hat{R}_{k+l}\right]$ を表わしているもの之 し，次節以下でこの応用について言及する.

\section{4. 降雨予測の誤差確率を考慮した洪水流出予 測方法}

降雨予測の誤差確率を考慮した洪水流出予測をダム貯
水池のある流域に適用する手順について述べる.

\section{（1）レーダ雨量計による降雨予測の実施}

時々刻々（たとえば 15 分ごと）得られるレーダ雨量 情報を用いて，移流モデルによる方法，関連係数法等に より降雨予測を行う。

\section{（2）予測降雨の分散の算定}

レーダ雨量計による降雨観測結果を用いて，（1）の 
方法により降雨予測を行い，レーダ雨量計ごとに式 ( 2) の $a_{p}$ を同定しておく.

\section{（3）洪水流出モデルの定数の同定}

レーダ雨量計による雨量情報によりそれぞれの河川に おいて適用性の確認されている洪水流出モデルの定数を 同定する.

\section{（4）予測降雨群の発生}

降雨と洪水流出量の関係は非線形なので，予測降雨の 確率分布がわかっても, それを単純に洪水流出量の確率 分布とすることはできない，そこで予測時間 $l$ に対する 予測誤差がおのおの独立であると仮定して，ここでは前 述のように降雨予測により算定した予測降雨を $E\left[\hat{R}_{k+l}\right]$ とし，かつ，分散が式 (2) に従うような正規乱数を発 生させ, これを予測降雨群として洪水流出モデルに入力 する.

\section{（5）ダム貯水池の予測流入量・水位の算定}

（4）で作成した予測降雨群を入力して，（3）の洪水 流出モデルにより洪水流出量を求める. この洪水流出量 をダム貯水池流入量とし，ある定められた洪水調節方式 に基づきダム貯水位を計算する。

\section{（6）予測流入量・水位の確率分布の計算}

（5）で求められたある時刻 $k$ から $l$ 時間先の予測流 量・ダム貯水位群おのおのの期待值 $E\left[Q_{k+l}\right], E\left[H_{k+l}\right]$ と分散 $V\left[Q_{k+l}\right], V\left[H_{k+l}\right]$ を計算し, 予測流入量・ダム 貯水位の標準偏差 $\sigma$ を求め, 予測の信頼幅を計算する.

（7）ある危険状態を示すダム貯水位を超える確率の 計算

（6）で求めた期待值 $E\left[H_{k+l}\right]$ と標準偏差 $\sigma$ から $l$ 時 間先の予測水位 $H_{k+l}$ が危険状態を示すダム貯水位 $H_{0}$ を 超える超過確率 $P\left\{H_{k+l} \geqq H_{0}\right\}$ は正規分布を仮定すれば次 式で算定される.

$$
\begin{aligned}
& P\left\{H_{k+l} \geqq H_{0}\right\}=\int_{H_{0}}^{\infty} \frac{1}{\sqrt{2 \pi} \sigma} e^{-(x-\mu)^{2} / 2 \sigma^{2}} d x \cdots \cdots \cdots . . . \\
& \text { ここに, } x=H_{k+l} \\
& \quad \mu=E\left[H_{k+l}\right] \\
& \text { ここで, } \frac{x-\mu}{\sigma}=Z, \frac{H_{0}-\mu}{\sigma}=Z_{1} \text { とおけば, } \\
& P\left\{H_{k+l} \geqq H_{0}\right\}=\int_{Z_{1}}^{\infty} \frac{1}{\sqrt{2 \pi}} e^{-Z^{2} / 2} d z=\int_{Z_{1}}^{\infty} \Psi(z) d z
\end{aligned}
$$

となる。

この $\Psi(Z)=\frac{1}{\sqrt{2 \pi}} e^{-Z^{2} / 2}$ は標準正規分布 $N(0,1)$ で

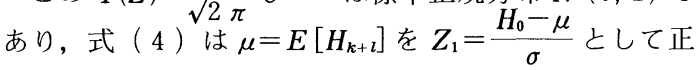
規化することで正規分布表から求めることができる.

\section{5. 比較的流域面積の小さい洪水調節ダムへの 適用例}

前節で述べた降雨予測の誤差確率を考慮した洪水流出
予測手法を比較的流域面積の小さい河川の洪水調節ダム を想定し，その有用性を検討する.

\section{（1）想定ダム流域と対象降雨}

想定ダム流域は，レーダ雨量計の降雨観測記録が存在 し, かつ, 洪水調節容量が比較的小さく, 但し書き操作 （洪水調節容量を超えるダム流入量があると予想される 場合の操作で, ダム流入量 =ダム放流量としてダム貯水 位がダム設計水位を超えることを防ぐために行われる) を行って下流の洪水氾濫をかろうじて防止したダム流域 とする.

このダム流域では, 昭和 63 年 7 月 15 月末明より降り 始めた前線性降雨により, 貯水池には, 計画高水流量を はるかに超過した流入があり，但し書き操作によって洪 水調節し，下流の被災を防ぐことができた.

ここでは, 対象降雨としてこの昭和 63 年 7 月 15 日の 前線性降雨を用いるものとする.

\section{（2） 想定ダムの諸元}

想定ダムの諸元を表一3に示す.

\section{(3) 降雨予測}

レーダビーム高度 $3000 \mathrm{~m}$ 以下の範囲内のデータから 移流モデルによる方法を用いて想定ダム流域の降雨予測 を行った. 実測雨量と予測雨量の相関係数は，1，2，3， 4 時間先の予測值に対し, それぞれ $0.935,0.633,0.311$, 0.498 である. 4 時間先の相関係数が大きいのは, 計算 サンプル数が他の場合に比較して少ないことによるもの と思われる。

\section{（4）予測降雨の分散}

式（2）を用いて求めるが，当該ダム流域を観測して いるレーダ雨量計は昭和 61 年 9 月から運用開始された もので, データが少なく $a_{p}$ が求められていないことか ら, 便宜的に八重岳レーダ雨量計で同定された $a_{p}=$ 0.465 を用いる.

\section{（5） 洪水流出モデルと定数の同定}

通常, 洪水流出モデルは対象とする流域の特性等によ り流出モデルを選定し，既往の降雨と出水記録から流出

\begin{tabular}{|c|c|}
\hline 集水面䅡 & $33.8 \mathrm{kal}$ \\
\hline 堤高 (コンクリートタム) & $59.7 \mathrm{~m}$ \\
\hline 洪水調節容量 & 435 万 $\mathrm{m}^{2}$ \\
\hline 有効利用水深 & $27.9 \mathrm{~m}$ \\
\hline 湛水面䅡 & $27 \mathrm{ha}$ \\
\hline 計画高水流量 & $430 \mathrm{~m}^{2} / \mathrm{s}$ \\
\hline 但し草き操作閒始水位 & $139 m$ \\
\hline サーチャージ水位 & $142.5 \mathrm{~m}$ \\
\hline
\end{tabular}
モデルの定数を同定する.

ここでは, 貯留関数法を用いることとし，昭和 63 年 7 月 15 日のレーダ雨量計記録と想定ダムの流入量をも

\section{表一3 想定ダムの諸元}


とに定数を同定した.

（6）予測降雨群における予測降雨の必要サンプル数

ある母集団の期待值をある信頼度で推定しようとすれ ば，母集団がサンプル数に対して十分大きな場合の必要 サンプル数は次式で求めることができる.

$$
n=\left[\frac{x}{F}\right]^{2} \cdot \sigma^{2}
$$

ここに, $n$ : 必要サンプル数

$x:$ 基準化された正規変数

$F ：$ 許容誤差

$\sigma^{2}:$ 分散

いま, $90 \%$ の信頼度で期待値の $10 \%$ の誤差を許容す るとすれば, $x=1.64, F=0.1 \mu$ となる.これを式 $(5)$ へ代入し，かつ， $\sigma^{2} に$ 式 $(2)$ を適用すれば,

$$
n=\left[\frac{1.64}{0.1 \mu}\right]^{2} \cdot a_{p}^{2} \cdot l \cdot \mu^{2}=1.64^{2} \times 0.465^{2} \times l \times 10^{2}
$$

となる。

4 時間先の予測に対し, 必要なサンプル数を式（6） で求めると $n=233$ となる. したがって, 正規乱数の発 生回数は 250 回で十分と考えられる.

\section{（7） 洪水調節方式}

洪水調節は次のような一定率, 一定量調節方式を考え る.

$Q_{o}(t)=\left(Q_{i}(t)-Q_{c}\right) \times \alpha+Q_{c}$

ただし， $Q_{0}(t) \geqq 130 \mathrm{~m}^{3} / \mathrm{s}$ のときは， $Q_{o}(t)=130 \mathrm{~m}^{3} / \mathrm{s}$

ここに, $Q_{i}(t):$ 時刻 $t$ のダム流入量 $Q_{o}(t)$ : 時刻 $t$ のダム放流量

$Q_{c}$ : 洪水調節開始流量

(ここでは, $40 \mathrm{~m}^{3} / \mathrm{s}$ とする. )

$\alpha$ : 一定率

$$
\text { (ここでは, } \alpha=130 / 430 \text { とする.) }
$$

\section{（8）ダム貯水位の計算}

ダム貯水位は，上記洪水調節方式によってダム貯水位 貯水容量曲線を介して計算する.

\section{（9）検 討 結 果}

a) レーダ雨量計による降雨予测方法の有効性

図一3に従来の降雨予測手法（前 3 時間の平均值が今 後 3 時間継続すると仮定する方法）とレーダ雨量計によ る降雨予測手法を用いて，想定ダムの水位を予測した場 合の比較図を示す.

レーダ雨量計による降雨予測の方が従来の手法と比へ て予測水位と実水位の差が小さく，レーダ雨量計による 降雨予測を洪水流出予測に適用することが従来の予測手 法よりは有効であること，洪水のピーク時間より長時間 の洪水流出予测計算を行う場合は，レーダ雨量計による 降雨予測が不可欠であることを示唆している．ただし，

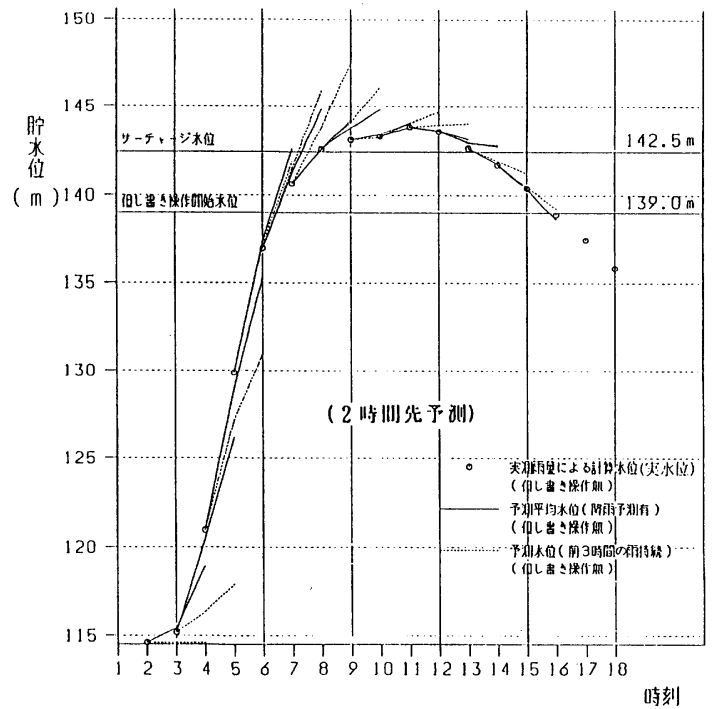

図一3 降雨予測方法の違いによるダム貯水池の予測水位の比較

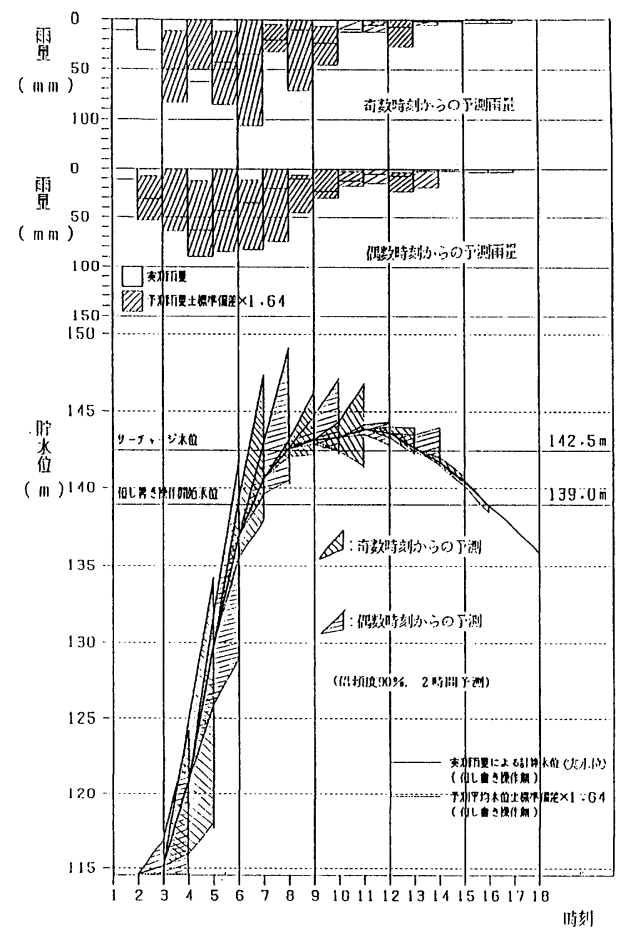

図一4レーダ雨量計を用いた降雨予測による貯水池の予測水位

図一3 は上記 2 手法の違いを比較検討したものであり， 当該流域における実測降雨をもとに「但し書き操作」を 行わず，先述の洪水調節が行われた場合に発生するであ ろうと予想される水位を「実水位」とよぶことにした。 この水位は，実際に想定ダムで発生した水位とは異なる ものである. 


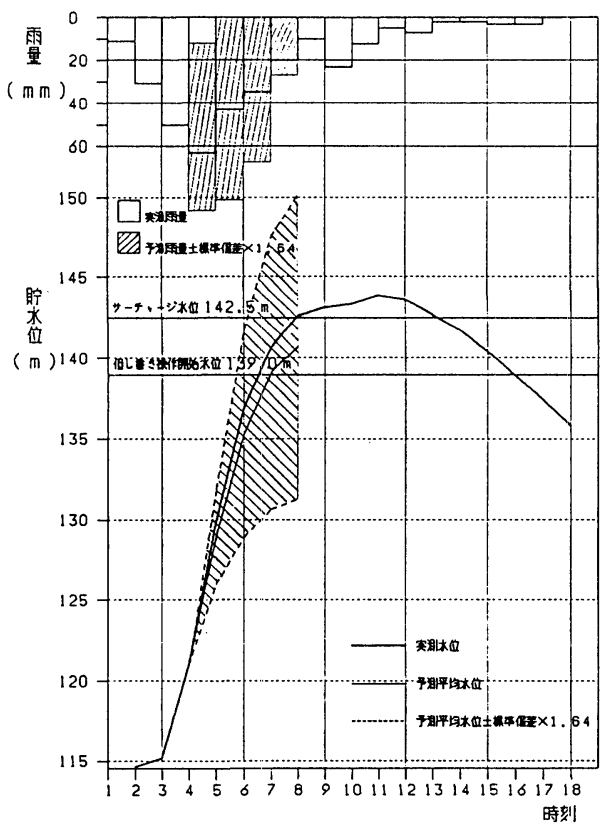

図一5(a) 午前 4 時における貯水池の予測水位

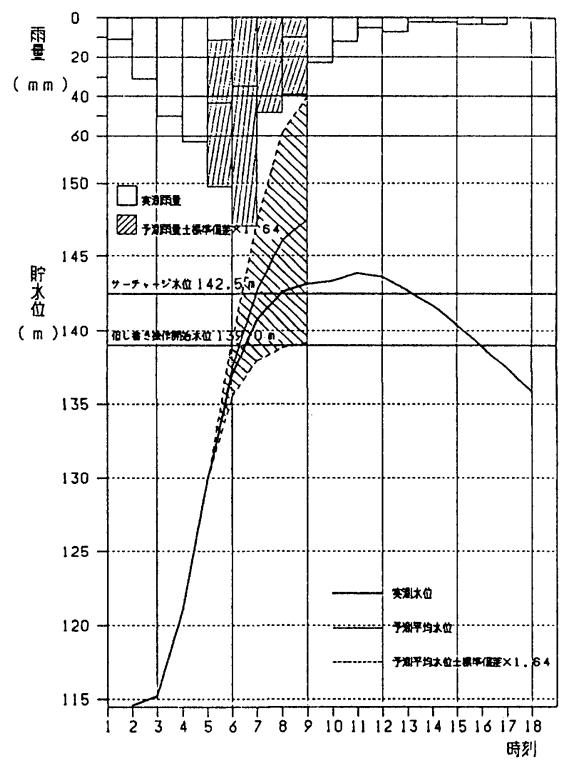

図一5(b) 午前 5 時における貯水池の予測水位

b）確率誤差を考虑した予測降雨の有効性

図一3によると，1 時間先の予測值であれば，予測降 雨の期待値（平均值）だけを用いたもので実水位に近い 水位を予測することができるが， 2 時間先以上の予測で は実水位と大きな差が生ずることがしばしば起こる，特 に増水時にその傾向が顕著になる。これは予測降雨の期 待值だけで 2 時間先以上の長時間の洪水流出予測を行う ことの危険性を示唆している.

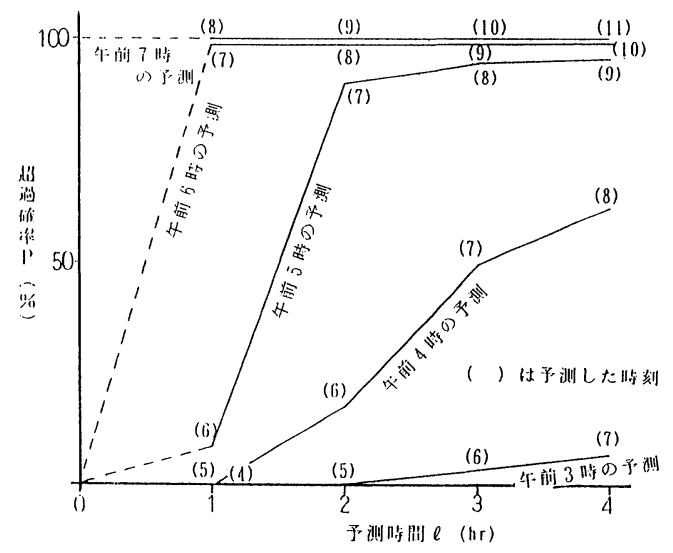

図一6 予測水位が「但し書き操作開始水位」を超える超過確率

そこで, 先述の誤差確率を考慮して 4 時間先までの予 測水位を検討し，この 2 時間先までの結果を信頼幅で示 したのが図一4である．実水位は $90 \%(1.64 \sigma)$ の信 頼幅の中に予測されている．参考として，図一5に午前 4 時および午前 5 時から 4 時間先までの予測水位を検討 した結果を抽出して示している.

c） ある危険状態を示す水位の判断の有効性

ダム操作はいかなる洪水に対しても的確に行わなけれ ばならない．このため，ダム貯水位が何時間後に危険状 態になるかを示す水位，たとえば「但し書き操作開始水 位」に到達するかを早期に把握し，関係機関およびダム 下流住民にあらかじめ放流に関する通知を行う必要があ る.

この点に留意して「但し書き操作開始水位」を超過す る確率を算定した結果，図一 6 に示すように午前 4 時の 予測時点ですでに 3 時間先に超過確率が $50 \%$ となり, 午前 5 時の予測時点では 2 時間先に $90 \%$ となることが 求められた。

すなわち，図一 5 と図一6を併用することで，安全側 の対応 (判断) をとるとすれば 3 時間前に，また超過確 率 $90 \%$ を判断限界とすれば 2 時間前には, 「但し書き 操作開始水位」を超えるダム貯水位となることが予測可 能となる.

\section{6. 結 論}

以上のように，洪水流出予測にはレーダ雨量計による 降雨予測が不可欠であり, さらに誤差確率を考慮するこ とで，特に増水期においては，ダムの洪水調節等に有効 な情報となることが明らかになった。本文で提案した方 法は予測降雨の期待値のみを入力して洪水流出予測をす る方法に比べてきわめて有効な判断情報となると考えら れる．また，本検討では降雨予測を 1 時間ごとにしてい 
るが,レーダ雨量計のデータは 5 分ごとに入手できるの で, 運用上は予測更新時間間隔を 10 分とか 15 分ごとに 短縮して行うことが可能であることから，本検討に比べ てよい精度の良い結果を得ることができると思われる.

\section{7. あとがき}

本文では, 従来研究されているレーダ雨量計による降 雨予測手法をもとに得られた予測降雨に確率誤差を評価 して, 従来利用されている洪水流出モデルに入力し, 洪 水流出予測の予測精度を求める方法を述べたが, 日野 ${ }^{17)}$, 高棹ら $^{51}$, 星 ${ }^{18)}$ の研究にみられるように洪水流出モデル のもつシステム誤差や雨量・水位等の観測誤差を考慮し た予測方法に発展させていく必要がある。

しかし，レーダ雨量計による予測降雨はその誤差確率 を考慮すれば洪水流出モデルに実用的に利用し得ること が明らかになったことから，本検討はダム貯水池による 効率的な洪水調節等に関する研究の一層の発展に役立つ ものと考えられる.

最後に，本文をまとめるにあたり，多くの示唆とご指 導を賜った早稲田大学 吉川秀夫教授と, ご協力をいた だいた（財）河川情報センター 村田和夫氏，(株) 建設 技術研究所 俞 朝夫氏に深甚の意を表するものである.

\section{参 考 文 献}

1) 上林 $\cdot$ 山口 · 山本 : レーダ定数 $(B, \beta)$ の同定手法の提 案, 土木学会論文集, 第 339 号 $/$ II - 10, pp. 121 130, 1988 年 11 月.

2）大倉・石崎・中尾・森下：レーダ雨量計を用いた短時間 降雨予測, 第 27 回水理講演会論文集, 1983.

3）椎葉・高棹・中北：移流モデルによる短時間降雨予測手 法の検討, 第 28 回水理講演会論文集, 1984 .

4) Clukie, I.D. and Owens, M.D. : Real time rainfall runoff models and use of weather radar information, Weather Radar and Flood Warning Symposium, 1985.

5）高棹・椎葉・宝：貯留モデルによる実時間流出予測に関 する基礎的研究, 京大防災研究所年報, 第 25 号 B-2, 1982.

6) 日本気象学会: 気象レーダ特集, 気象研究ノート, 139 号, 1980.

7) Austin, G.L. and Bellon, A. : The use of digital weather radar records for short-term precipitation forecasting, Q.J.R. Meteor. Soc., 100.

8) Asai, T., Yoshizaki, M. and Ishikawa, K. : Some results on an objective analysis for tracking radar echoes of convective clouds, J. Meteor. Soc. Japan, 55, 1977.

9) 石崎・中尾・森下：レーダ雨量計による短時間降雨予測, 土木学会第 15 回年次学術講演会講演概要集第 2 部, 1980.

10）建設省淀川ダム統合管理事務所：昭和 60 年度短時間降雨 予測検討業務報告書, 1986 .

11）建設省利根川ダム統合管理事務所：レーダ雨量計による 降雨予測システム開発業務報告書, 1982, 1983.

12）竹内邦良：雨域・雨量強度分布変化の短時間予測, 第 22 回水理講演会論文集, 1978 .

13）竹内邦良：降雨の短時間自動予測手法について, 山梨大 学工学部研究報告, 29, 1975.

14) Wilk, K. E. and Gray, K. C. : Processing and analysis techniques used with the NSSL Weather radar system, Proc. The 14th Radar Meteor. Conf., 1970.

15) David Zittel, W. : Computer applications and techniques for storm tracking and warning, The 17th Radar Meteor. Conf., 1976.

16）吉野・水野・俞：雨域追跡法による短時間降雨予測の精 度, 第 31 回水理講演会論文集, 1987.

17）日野幹雄：水文流出系予測へのカルマン・フィルター理 論の適用, 土木学会論文報告集, 第 221 号, 1974 .

18）星 清：洪水予測システムの基礎的検討 (1),(2), 土木試験所月報, No. 385, 1985, No. 386, 1986 .

(1989.1.9 - 受付) 